\title{
The behaviour of SMEs' capital structure determinants in different macroeconomic states
}

\author{
Nikolaos Daskalakis $^{a^{*}}$, Dimitrios Balios ${ }^{\mathrm{b}}$, Violetta Dalla ${ }^{\mathrm{b}}$
}

\footnotetext{
a University of Brighton, Brighton Business School

${ }^{\mathrm{b}}$ National and Kapodistrian University of Athens, Department of Economics
} 


\title{
The behaviour of SMEs' capital structure determinants in different macroeconomic states
}

\begin{abstract}
The recent global financial crisis has triggered questions in the scientific area of capital structure dynamic determination regarding how "quickly" companies tend to adjust their capital structure to their long-term targets, in different macroeconomic states. We broaden the scope of the debate by focusing on SMEs and by discussing the relative importance of firm-specific and macroeconomic variables, when macroeconomic conditions change. Based on a partial adjustment model, we find that short-term and long-term debt ratios follow different patterns regarding their adjustment speeds; the adjustment speed for long-term debt slows down during the crisis, while the respective of the short-term debt is not affected. We also find clear differentiations of the effects and the contribution of the firm-specific and the macroeconomic variables between short-term debt and long-term debt ratios, when macroeconomic states change. We thus conclude that the nature and maturity of borrowing affect the persistence and endurance of the relationship between determinants and borrowing, across different macroeconomic states.
\end{abstract}

\section{Keywords}

SMEs, corporate finance, financial leverage, capital structure, macroeconomic states

\section{JEL Classification}

G3, G32, M21 


\section{Introduction}

Capital structure determination of Small and Medium Enterprises (SMEs) is a scientific area that has drawn much of research interest mainly during the last two decades. This is partly because of the recognition of the importance of SMEs for the economy in terms of numbers of enterprises, employment and value added, and partly because of the acknowledgement that SMEs financing exhibits considerable differences when compared to large enterprises. Consequently, a series of research has emerged, especially during the last twenty years that focuses on investigating the particularities of small enterprises in their capital structure determination.

Specifically, Torrès and Julien (2005) tackle this issue from a managerial perspective and describe the main findings of researchers over the last 30 years that have led to the recognition of SMEs specificities. Capital structure theory cannot be an exemption of this wide recognition, where research has shown that large firms' theory has limited applicability to SMEs. This approach was first highlighted by Ang (1991), who points out that the theory of finance was not developed with the small business in mind, while Cressy and Olofsson (1997) state that small businesses are not "scaled-down versions" of large businesses, and Michaelas et al. (1999) attempt to relate the different theoretical attributes to small firms.

On the other hand, Hackbarth et al. (2006) denoted that, despite the substantial development of the capital structure literature, little attention has been paid to the effects of macroeconomic conditions on credit risk and capital structure choices. The recent global financial crisis has triggered questions in the scientific area of capital structure determination regarding how "quickly" companies tend to adjust their capital structure to their long-term targets, in different economic states. Cook and Tang (2010) build on the findings of previous analysts (Choe et al., 1993; Gertler and Gilchrist, 1993; Korajczyk and Levy, 2003) that macroeconomic conditions do affect firms' financing choices, and show that firms adjust their leverage toward target faster in good macroeconomic states relative to bad states. Öztekin and Flannery (2012) compare capital structure speed adjustments across countries and find that legal and financial conditions vary with debt adjustment speeds. Baum et al. (2016) follow a similar approach and show that firms with financial surpluses and above-target leverage adjust their leverage more rapidly when firm-specific risk is low and when macroeconomic risk is high, while firms with financial deficits and below-target leverage adjust their 
capital structure more quickly when both types of risk are low. It is exactly the context of Baum et al. (2016) which triggers the main idea of this paper, namely to investigate the relative importance of traditional firm-specific capital structure determinants (i.e. asset structure, size, profitability, risk, growth etc.) versus macroeconomic variables, when macroeconomic states change.

None of the afore-mentioned studies simultaneously combine SMEs' specificities with adjustment speed in capital structure determination and explore the issue of firmspecific vs. macroeconomic variables in different economic states. The main research objective of this paper is thus to contribute to the interesting debate of the relative importance of firm-specific vs. macroeconomic variables when macroeconomic conditions change, seen respectively in a demand-driven vs. supply-driven context, in the SMEs environment.

We identify two periods of different macroeconomic states (growth and recession) and mainly follow the methodological rationale of Cook and Tang (2010) and Öztekin and Flannery (2012), using a dynamic partial adjustment capital structure model with unobserved heterogeneity and dummy variable for the macroeconomic states. Our main finding is that there are clear differentiations of the effects and the contribution of the firm-specific vs. the macroeconomic variables between short-term debt and long-term debt ratios, when macroeconomic states change. This finding leads to the conclusion that the nature and maturity of borrowing affects the persistence and endurance of the relationship between determinants and borrowing, across different macroeconomic states.

We thus believe that the paper contributes on the recent of capital structure dynamic determination in the following ways: (a) we broaden the scope of the debate by including SMEs, (b) we show that macroeconomic states have a prevailing effect on how the relationships of capital structure determinants and leverage are shaped, and (c) we show that these relationships are also influenced by debt maturity.

The rest of the paper is as follows. Section 2 describes the model, the methodology, the variables and the data, Section 3 presents the empirical results and Section 4 concludes the paper. 


\section{Methodology and data}

\subsection{The model}

We mainly follow the rationale of Cook and Tang (2010) and Öztekin and Flannery (2012), using the partial adjustment model which assumes that the target debt ratio $D R_{i, t}^{*}$ of firm $i$ at time $t$ is given by:

$$
D R_{i, t}^{*}=\alpha^{*}+\alpha_{i}^{*}+\beta^{*} X_{i, t-1}+\gamma^{*} M_{t-1}, \quad i=1, \ldots, N, t=2, \ldots, T_{i}
$$

where $\alpha^{*}$ is the constant term, $\alpha_{i}^{*}$ is the unobserved heterogeneity of firm $i, X=$ $\left(X_{1}, \ldots, X_{K}\right)^{\prime}$ and $M=\left(M_{1}, \ldots, M_{J}\right)^{\prime}$ are (column) vectors of firm specific and macroeconomic variables respectively, $\beta^{*}=\left(\beta_{1}^{*}, \ldots, \beta_{K}^{*}\right)$ is the (row) coefficient vector of the firm specific variables and $\gamma^{*}=\left(\gamma_{1}^{*}, \ldots, \gamma_{J}^{*}\right)$ the (row) coefficient vector of the macroeconomic variables. The debt ratio $D R_{i, t}$ adjusts to its target according to the rule:

$$
D R_{i, t}-D R_{i, t-1}=\delta^{*}\left(D R_{i, t}^{*}-D R_{i, t-1}\right)+\varepsilon_{i, t}
$$

where $\delta^{*}$ is the speed of adjustment and $\varepsilon_{i, t}$ is the error term. Solving equations (1) and (2) for $D R_{i, t}$ gives

$$
D R_{i, t}=\alpha+\alpha_{i}+\delta D R_{i, t-1}+\beta X_{i, t-1}+\gamma M_{t-1}+\varepsilon_{i, t}
$$

where $\alpha=\delta^{*} \alpha^{*}, \delta=1-\delta^{*}, \beta=\delta^{*} \beta^{*}, \gamma=\delta^{*} \gamma^{*}$ and $\alpha_{i}=\delta^{*} \alpha_{i}^{*}$.

Cook and Tang (2010) estimate model (3) using panel data for US firms over the period 1977-2006, while Öztekin and Flannery (2012) for companies from 37 countries over the period 1991-2006. Cook and Tang (2010) expand further the model by including a dummy variable for the good and bad states of the economy and interacting it with the lagged debt ratio. They find that the speed of adjustment is lower in bad states compared to good states of the economy. Öztekin and Flannery (2012) find that the countries with low speed of adjustement are those with weak financial, legal and political institutions, not allowing however for different speeds of adjustment in different states.

Since our sample period contains a good (growth) followed by a bad (recessionary) macroeconomic state, it is unlikely that the coefficients in (3) remain constant over time. Hence, we follow Cook and Tang (2010) and consider a dummy variable for the good and the bad states. We interact the dummy with the lagged debt ratio as in Cook and Tang (2010), but also with the lagged firm-specific and macroeconomic variables in order to investigate the effect of these distinct sets of variables to debt ratio in different macroeconomic states. The inclusion of these multiplicative dummies is 
essential from a methodological perspective. Since we are considering the possibility that the adjustment rate $\delta^{*}$ is different in the two periods, then the coefficients of the firm and macro regressors are likely to be different in the two states given that $\beta=$ $\delta^{*} \beta^{*}$ and $\gamma=\delta^{*} \gamma^{*}$.

The model becomes:

$$
\begin{aligned}
D R_{i, t}= & \alpha+\alpha_{i}+\alpha^{c} C_{t}+\delta D R_{i, t-1}+\delta^{c} D R_{i, t-1} C_{t}+\beta X_{i, t-1}+\beta^{c} X_{i, t-1} C_{t}+ \\
& \gamma M_{t-1}+\gamma^{c} M_{t-1} C_{t}+\varepsilon_{i, t}
\end{aligned}
$$

where $C_{t}$ takes the value 1 if $t$ is in the crisis period and 0 otherwise. Under this setup, the effects of the lagged debt ratio, the lagged firm-specific variables and the lagged macroeconomic variables on the debt ratio are given respectively by $\delta, \beta$ and $\gamma$ in the good state and by $\delta+\delta^{c}, \beta+\beta^{c}$ and $\gamma+\gamma^{c}$ in the bad state. The differences of these effects in the two periods are given by $\delta^{c}, \beta^{c}$ and $\gamma^{c}$, respectively. Once we estimate model (4), we focus on hypothesis testing for the significance of the latter parameters to examine the effect of firm and macro variables on debt ratio in different states. Since we do find evidence that there are different effects, we further decompose the sample mean of debt ratio and investigate the relative contribution of the firm and macro variables.

\subsection{The Estimation Methodology}

We estimate model (4) with the two-step system generalized method of moments (GMM) of Arellano and Bover (1995) and Blundell and Bond (1998). We do not include the dummy for the constant (i.e. set $\alpha^{c}=0$ ), since the dummy variable is highly collinear with some of the regressors, and drop the constant (i.e. set $\alpha=0$ ) as it is found insignificant. We use one lag for the instruments in the GMM estimation and robust (to small samples) standard errors of Windmeijer (2005). The estimation method is designed for big $\mathrm{N}$ and small $\mathrm{T}$ dynamic panels with high autoregressive parameter, and while it requires the error term $\varepsilon_{i, t}$ to have no autocorrelation (so that the moments conditions are satisfied for performing GMM), it does not restrict it to be homoskedastic.

As regards diagnostic tests, we evaluate the Wald statistic for goodness-of-fit, the Arellano and Bond (1991) statistic for autocorrelation in the first-differenced residuals $\Delta \hat{\varepsilon}_{i, t}$, the modified Wald statistic for heteroskedasticity evaluated for the residuals $\hat{\varepsilon}_{i, t}$, (see Greene, 2000) and the Sargan and Hansen statistics for overidentifying restrictions 
(see Sargan, 1958, and Hansen, 1982). We also examine the fit of the model by evaluating the coefficient of determination $R^{2}$ of model (4) for the whole period and the two subperiods, with and without the estimated fixed effects ${ }^{1}$.

To evaluate the robustness of our results, we 1) allow for maximum lag in the instruments for the difference equation in system GMM estimation, 2) take a full balanced subsample of the data, 3) examine firm with total debt ratio less than 1 for all available years, 4) consider only firms with non-zero debt for all available years, 5) split the sample in the two periods, 6) replace the macro regressors by year dummies, and 7) consider different break point of when the crisis occurs.

\subsection{The variables}

\subsubsection{Measurement of leverage}

We differentiate between three types of leverage, namely the total debt ratio (TDR), the short-term debt ratio (STDR) and the long-term debt ratio (LTDR), following a respective strand of literature that approaches debt maturity differentiation from different angles (Diamond and He, 2014; Fan et al., 2012; Fu and Subramanian, 2011. On SMEs: Koeter-Kant and Hernandez-Canovas, 2011; García-Teruel, and MartínezSolano, 2010; Michaelas et al., 1999). This differentiation allows us to examine influences of the debt maturity structure on leverage, across macroeconomic states.

In terms of calculating the ratios, we follow standard practice by measuring debt ratios as the book value of interest-bearing debt over total assets. Thus, TDR is the sum of the firm's short-term plus long-term book value of interest-bearing debt to total assets, while STDR and LTDR are short- and long-term debt to total assets respectively.

\subsubsection{Firm-specific factors}

We use the standard set of firm-specific capital structure determinants for SMEs.

Asset structure (AS) is expected to be either positively related with debt levels, since banks require guarantees from SMEs to grant loans (Scott, 1977; Harris and Raviv, 1990), or positively related since asset tangibility is related with a stable source of internally generated returns (Hall et al., 2004; Sogorb-Mira, 2005). AS is measured as the ratio of tangible assets to total assets.

\footnotetext{
${ }^{1}$ We calculate $R^{2}=1-S S R / S S T$, where $S S T$ is the sum of squares of the debt ratio $D R_{i, t}$ and $S S R$ is sum of squares of either the residuals $\hat{\varepsilon}_{i, t}$ or the composite residuals $\hat{\alpha}_{i}+\hat{\varepsilon}_{i, t}$.
} 
Size (SIZE) is expected to be positively related with debt levels since larger enterprises are more diversified and are expected to go bankrupt less often, while smaller firms are usually more opaque as well. Therefore, larger firms are expected to show higher levels of financial leverage (Ang et al., 1982; Pettit and Singer, 1985). SIZE is measured as the natural logarithm of total sales.

According to Myers (1977) firms with growth potential are considered as riskier and will tend to have lower leverage. On the other hand, firms with high growth opportunities are more likely to exhaust internal funds and seek external financing (Michaelas et al., 1999). Therefore, the relationship of growth (GR) and leverage can be either negative or positive. GR is calculated as the annual rate of change in sales.

In the context of the pecking order theory, SMEs financing decisions generally follow a hierarchy, with a preference for internal over external financing and for debt over equity (Michaelas at al., 1999; Daskalakis and Psillaki, 2008; Psilaki and Daskalakis, 2009). Hence, profitability (PR) is expected to be negatively related to debt and is measured as earnings before interest and taxes to total assets.

Tax considerations are of little attention for SMEs (Pettit and Singer, 1985), because these firms are less likely to generate high profits and therefore less likely to use debt, or non-debt items for tax shields. However, based on the given higher levels of difficulty for small firms to access debt financing, the use of non-debt tax shields (NDTS) could be viewed as their main alternative to reduce any tax burdens. Thus, nondebt tax shields will be either not related or negatively related to debt (Titman and Wessels, 1988). NDTS is measured as the ratio of total depreciation expenses to total assets.

Riskier firms (RISK) will have to confront relatively higher levels of difficulty in accessing debt financing (DeAngelo and Masulis, 1980; Titman and Wessels, 1988). We therefore expect a negative relationship between risk and leverage. To calculate RISK, we consider a three-year rolling window of the standard deviation of earnings before interest and taxes.

The importance of trade credit (NTCS) as a source of short-term financing, especially for SMEs is well documented (Ng et al., 1999; Asselbergh, 2002; Guariglia and Mateut, 2006). There are two alternative hypotheses in the literature for the use of trade credit: the substitution hypothesis and the complementarity hypothesis, and evidence shows that during times of tight money, trade credit acts as complement rather than substitute to bank credit, providing support for the redistribution effect (Love et 
al., 2007; Casey and O’Toole, 2014; Psillaki and Eleftheriou, 2015). We thus either expect a positive or a negative relationship of trade credit before the crisis, following the complementarity or the substitution hypothesis respectively, and a positive relationship during the crisis. Regarding NTCS, we follow the net-trade-credit approach of Love et al. (2007); we first subtract trade payables from trade receivables and then divide by total sales.

Cash-rich companies (CASHTA) are also expected to have lower debt for two reasons. First, risky firms will try to accumulate cash to avoid under-investment issues in the future, and second, cash-rich firms will prefer internal financing as explained in the pecking theory context. CASHTA is calculated as cash to total assets.

Last, to capture the fact that each firm faces different interest burden, we consider the firm-specific time varying interest burden (FINEXP), expecting a negative relationship between the lagged value of financial burden and leverage. We compute FINEXP as the financial expenses to sales ratio.

\subsubsection{Macroeconomic factors}

Mokhova and Zinecker (2014) provide an extensive literature review on the specific issue of the effect of various macroeconomic factors on corporate capital structure. Given that the most common source of external financing for SMEs is commercial banks (Colombo and Grilli, 2007; De Bettignes and Brander, 2007) we use credit supply (CRED) as one of our macroeconomic variables, expecting a positive relationship between credit supply (either expansion during the growth stage or contraction during the recessionary stage) and leverage. CRED is the annual growth rate of total credit expansion to enterprises and households.

The inflation rate (INFL) is another widely investigated macroeconomic factor. There is conflicting evidence however regarding the effect of inflation on capital structure. Bastos et al. (2009) find no effect of inflation on leverage, whereas Frank and Goyal (2009) find a positive relation between inflation and market leverage, but no relation on book leverage. Hanousek and Shamshur (2011) find that inflation generally has a positive influence on leverage, but this effect turns insignificant for certain specifications of their model. We take as INFL the annual rate of change of the CPI index.

Another important macroeconomic factor is the interest rate on which firms borrow, which represents the cost of debt. Researchers have examined the relation between interest rates, firm's leverage and macroeconomic conditions (e.g. Karpavičius and Yu, 
2017; Halling and Zechner, 2016; Baum et al., 2009; Frank and Goyal, 2004; Korajczyk and Levy, 2003) and the empirical evidence on the relation between firm's leverage and interest rates is varied. Most of the researchers, however, do not approach the relationship from the firm's perspective, namely that firms borrow more money when borrowing costs are lower. An exemption is Karpavičius and Yu (2017), who conclude that firms do not adjust their capital structures based on interest rates, except when they expect a recessionary period. On the other hand, during periods of recession, interest rates tend to be lower due to interventions by the Central Bank's monetary policy, but firms also lower their demand for external financing. Thus, the relationship can result in a positive sign as firms are reluctant to borrow money even if the interest rates are low, as their target ratios are lower. We use the published figures of the Central Bank reports, namely the interest rates on outstanding amounts of euro-denominated loans to non-financial corporations by maturity. Specifically, since we use three different types of leverage, we adjust the interest rate variable (INTR) to each type, meaning that we use interest rates for short-term and long-term debt, while the interest rates variable for total debt is the average of the two.

\subsection{The data}

We use data from published financial statements of SMEs operating in Greece during 2004-2014, a period covering both growth and recession. We believe that the choice of Greece adds to the particularity of this research effort, since the Greek economy simultaneously gathers the following characteristics: (a) a developed economy, member of a community of developed economies in terms of financial infrastructure, (b) a country where the SMEs sector is relatively more important when compared to other economies in EU-28, and mostly (c) because of the clear distinction between two different macroeconomic states (growth and recession) that took place during 2004-2014 as Greece is the country which is hit perhaps the most severely by the recent economic crisis.

The choice of Greece does not restrict results and conclusions from being generalized to economies with similar characteristics. Psillaki and Daskalakis (2009) investigate capital structure determination for SMEs in four European countries (Greece, Italy, France and Portugal) and conclude that the four countries present similar financial and institutional characteristics. They find similarities in the determinants of capital structure across their sample countries, attributed to the commonality of the 
institutional and legal characteristics of the four countries, and ultimately, that firm rather than country factors explain differences in the intensity of capital structure choices.

Our data sources are the ICAP database and the Bank of Greece. The ICAP database consists of the published financial statements of all companies that are obliged to report them (i.e. the companies with legal form of a limited liability company). We drop firms whose accounting information is not full for at least four consecutive years and remove firms with outliers. Our final sample is thus an unbalanced sample of 17,317 nonfinancial SMEs in Greece during the period 2004-2014. Our sample contains 159,030 observations and 31,457 missing values. We use the databases of the Bank of Greece for the macroeconomic variables.

Our sample contains all business economy sectors except for financial, insurance and real estate activities, as is the common practice in the capital structure research field. Approximately $72 \%$ of the sample firms are micro, $24 \%$ small and $4 \%$ medium $^{2}$. In terms of the sectoral breakdown, almost $36 \%$ of firms are in the wholesale and retail trade, $28 \%$ in manufacturing, $29 \%$ in the service sectors and the remainder $7 \%$ in construction $^{3}$.

We set the cut point between the growth and the recession states in 2009 since it is in this year when annual GDP growth rate becomes substantially negative, and firms' average total assets and average total debt also begin to drop. We thus define our growth period during 2004-2008 and the recession period during 2009-2014.

Table 1 presents annual summary statistics (sample mean and standard deviation) of the total values of the three forms of debt (total, short-term and long-term) and of the firm-specific variables, whereas Figure 1 depicts the data for the macroeconomic variables.

\footnotetext{
${ }^{2}$ We follow the European definition of SMEs to differentiate between micro, small and medium firms. The respective population percentages for the size criterion in Greece are on average for the examined period $96.5 \%$ for micro, 3\% for small and $0.5 \%$ for medium according to the SBA for Europe (Small Business Act - European Commission).

${ }^{3}$ On a population basis, $36 \%$ of firms are in the wholesale and retail trade, $25 \%$ in manufacturing, $27 \%$ in the service sectors and the remainder $12 \%$ in construction.
} 
Table 1

Sample descriptive statistics: firm-specific variables

Sample mean (MEAN) and standard deviation (SD) of total debt (TDEBT), short-term debt (SDEBT), long-term debt (LDEBT), total debt ratio (TDR), short-term debt ratio (STDR), long-term debt ratio (LTDR), asset structure (AS), size (SIZE), growth (GR), profitability (PR), non-debt tax shield (NDTS), risk (RISK), trade credit (NTCS), cash to total assets ratio (CASHTA) and financial expenses ratio (FINEXP). Values in bold show maximum values per variable.

\begin{tabular}{|c|c|c|c|c|c|c|c|c|c|c|c|c|c|c|c|}
\hline \multicolumn{16}{|c|}{ MEAN } \\
\hline YEAR & TDEBT & SDEBT & LDEBT & TDR & STDR & LTDR & AS & SIZE & GR & PR & NDTS & RISK & NTCS & CASHTA & FINEXP \\
\hline 2004 & 700,997 & 498,788 & 202,210 & 0.181 & 0.132 & 0.049 & 0.680 & 13.830 & 0.143 & 0.038 & 0.042 & 0.171 & 0.064 & 0.136 & 0.024 \\
\hline 2005 & 771,786 & 544,447 & 227,339 & 0.190 & 0.138 & 0.052 & 0.678 & 13.840 & 0.101 & 0.027 & 0.041 & 0.096 & 0.082 & 0.129 & 0.026 \\
\hline 2006 & 876,314 & 580,862 & 295,452 & 0.202 & 0.143 & 0.058 & 0.671 & 13.909 & 0.167 & 0.030 & 0.039 & 0.096 & 0.095 & 0.131 & 0.028 \\
\hline 2007 & $1,005,522$ & 603,954 & 401,567 & 0.210 & 0.141 & 0.068 & 0.661 & 13.999 & 0.177 & 0.036 & 0.037 & 0.098 & 0.099 & 0.133 & 0.031 \\
\hline 2008 & $1,150,947$ & 678,515 & 472,432 & 0.216 & 0.143 & 0.073 & 0.675 & 14.042 & 0.125 & 0.027 & 0.036 & 0.100 & 0.125 & 0.125 & 0.035 \\
\hline 2009 & $1,147,114$ & 644,604 & 502,510 & 0.228 & 0.143 & 0.085 & 0.686 & 13.906 & -0.051 & 0.013 & 0.035 & 0.111 & 0.159 & 0.132 & 0.034 \\
\hline 2010 & $1,082,271$ & 607,795 & 474,476 & 0.215 & 0.132 & 0.083 & 0.698 & 13.766 & -0.045 & -0.004 & 0.035 & 0.123 & 0.180 & 0.125 & 0.038 \\
\hline 2011 & 1,049,191 & 638,687 & 410,504 & 0.208 & 0.135 & 0.073 & 0.558 & 13.904 & -0.064 & -0.014 & 0.031 & 0.146 & 0.214 & 0.123 & 0.049 \\
\hline 2012 & $1,021,043$ & 571,737 & 449,306 & 0.204 & 0.124 & 0.080 & 0.777 & 13.713 & -0.053 & -0.019 & 0.034 & 0.137 & 0.246 & 0.127 & 0.055 \\
\hline 2013 & 955,062 & 512,661 & 442,401 & 0.198 & 0.118 & 0.080 & 0.842 & 13.626 & 0.059 & 0.005 & 0.026 & 0.127 & 0.285 & 0.140 & 0.063 \\
\hline 2014 & 988,097 & 532,304 & 455,793 & 0.196 & 0.115 & 0.081 & 0.846 & 13.743 & 0.103 & 0.017 & 0.025 & 0.133 & 0.276 & 0.146 & 0.056 \\
\hline
\end{tabular}

\begin{tabular}{|c|c|c|c|c|c|c|c|c|c|c|c|c|c|c|c|}
\hline \multicolumn{16}{|c|}{ STANDARD DEVIATION } \\
\hline YEAR & TDEBT & SDEBT & LDEBT & TDR & STDR & LTDR & AS & SIZE & GR & PR & NDTS & RISK & NTCS & CASHTA & FINEXP \\
\hline 2004 & 1,635,911 & 1,206,993 & 841,011 & 0.199 & 0.171 & 0.115 & 0.645 & 1.576 & 0.630 & 0.122 & 0.047 & 0.283 & 0.741 & 0.163 & 0.066 \\
\hline 2005 & $1,763,216$ & $1,299,850$ & 888,452 & 0.207 & 0.177 & 0.120 & 0.653 & 1.562 & 0.607 & 0.114 & 0.045 & 0.177 & 0.847 & 0.158 & 0.087 \\
\hline 2006 & $1,956,775$ & $1,360,851$ & $1,049,590$ & 0.214 & 0.181 & 0.127 & 0.657 & 1.568 & 0.626 & 0.116 & 0.044 & 0.178 & 0.792 & 0.158 & 0.121 \\
\hline 2007 & $2,232,736$ & $1,375,288$ & $1,353,942$ & 0.220 & 0.178 & 0.139 & 0.653 & 1.566 & 0.627 & 0.119 & 0.043 & 0.177 & 0.745 & 0.157 & 0.090 \\
\hline 2008 & $2,545,584$ & $1,570,068$ & $1,500,557$ & 0.224 & 0.181 & 0.141 & 0.660 & 1.576 & 0.606 & 0.119 & 0.044 & 0.172 & 0.869 & 0.154 & 0.105 \\
\hline 2009 & $2,529,102$ & $1,503,079$ & $1,537,092$ & 0.224 & 0.177 & 0.148 & 0.668 & 1.586 & 0.480 & 0.116 & 0.041 & 0.192 & 0.937 & 0.159 & 0.083 \\
\hline 2010 & $2,500,126$ & $1,551,232$ & $1,489,683$ & 0.226 & 0.175 & 0.150 & 0.685 & 1.601 & 0.502 & 0.122 & 0.041 & 0.218 & 1.025 & 0.157 & 0.125 \\
\hline 2011 & $2,433,389$ & $1,624,583$ & $1,317,444$ & 0.228 & 0.178 & 0.144 & 0.520 & 1.534 & 0.561 & 0.127 & 0.038 & 0.246 & 1.204 & 0.159 & 0.346 \\
\hline 2012 & $2,405,130$ & $1,502,436$ & $1,454,663$ & 0.233 & 0.174 & 0.154 & 0.733 & 1.623 & 0.578 & 0.121 & 0.040 & 0.241 & 1.292 & 0.161 & 0.200 \\
\hline 2013 & $2,355,494$ & $1,380,309$ & $1,511,383$ & 0.238 & 0.174 & 0.159 & 0.769 & 1.630 & 0.567 & 0.113 & 0.031 & 0.221 & 1.571 & 0.167 & 0.936 \\
\hline 2014 & $2,451,995$ & $1,485,046$ & $1,540,900$ & 0.244 & 0.176 & 0.162 & 0.768 & 1.640 & 0.582 & 0.114 & 0.031 & 0.233 & 1.613 & 0.168 & 0.352 \\
\hline
\end{tabular}


Looking at the relative trends of the three forms of debt in Table 1, total debt and short-term debt values rapidly increase until 2008 (and 2009 for long-term debt) and start decreasing slowly thereafter, but remain in relatively high values when compared with pre-crisis levels. Comparing between short- and long-term debt, the latter more than doubles during the growth period while the growth rate for the short-term debt is lower; there seems to be a relative preference of the firms towards long-term debt and this can be attributed to the relatively lower interest rates for long-term debt (Figure 1). Other interesting observations are that growth rates and profitability ratios start decreasing from 2008 already and that the net trade credit ratio gradually increases throughout the whole period, with an obvious jump during crisis years, which is evidence in favour of the redistribution approach.

Regarding the fluctuations of the macroeconomic variables, credit expansion is positive before crisis, drops significantly in 2009 and turns negative during the crisis period. There is a peak of inflation in 2010 which was due to the vast increase of VAT in an effort of the state to increase their revenues, followed by a gradual decline and negative figures thereafter. Last, interest rates peak at 2007-2008 and fluctuate thereafter at lower levels. Interestingly, interest rates for long-term loans are lower than those of short-term loans and while the latter remain at higher levels during the crisis than before the crisis, long-term rates remain at either the same or even at lower levels during the crisis, so that there is an increase in spreads between short-term and longterm interest rates during the crisis. It is worth noting here that, Greece being a member of Eurozone, base interest rates are set by the European Central Bank (ECB).

\section{Figure 1}

Annual data on credit expansion (CRED), inflation (INFL), and interest rates of total debt (INTR_TD), short-term debt (INTR_SD) and long-term debt (INTR_LD)
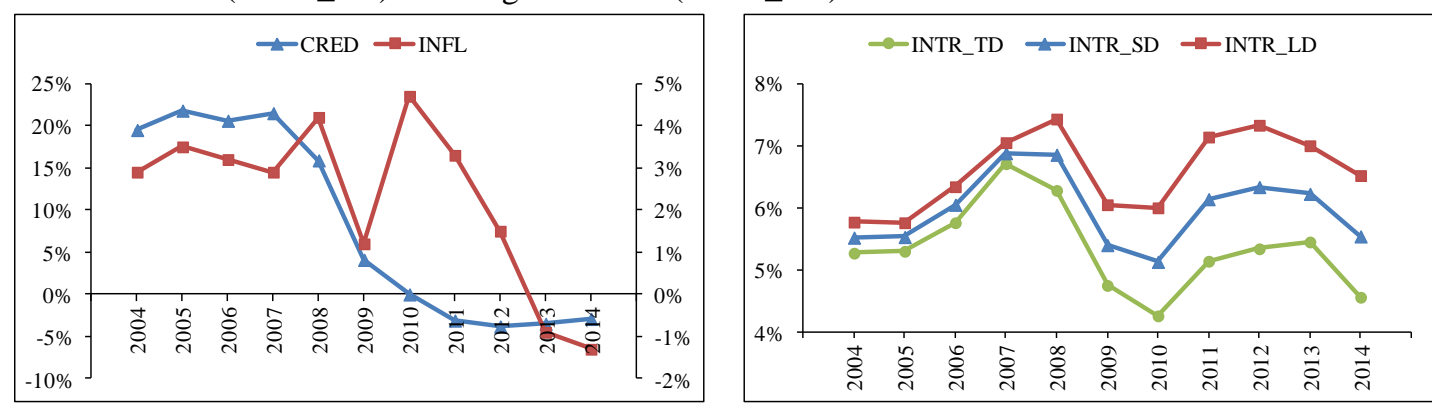


\section{Empirical results}

\subsection{Regression results}

The estimation results for model (4) are given in Table 2. Panel A presents the estimated coefficients of $\delta, \beta$ and $\gamma$ for 2005-2008, $\delta+\delta^{c}, \beta+\beta^{c}$ and $\gamma+\gamma^{c}$ for 2009-2014, whereas $\delta^{c}, \beta^{c}$ and $\gamma^{c}$ show the difference between the two periods; the zstatistic for significance is given in each case. Panel B contains the diagnostic tests and their associated p-values, while Panel $\mathrm{C}$ the coefficients of determination with and without the estimated fixed effects.

Results show that the main determinant of the debt ratio is its lagged value. The very high values of the estimates of the lagged debt ratio clearly suggest that the debt ratio exhibits very strong persistence ${ }^{4}$. A second and more interesting finding however is that there seems to be a different pattern regarding the adjustment speeds of short-term debt and long-term debt. Specifically, speed adjustments for TDR are 0.078 and 0.071 for the growth and recessionary periods respectively, but not significantly different, 0.099 and 0.113 for STDR and also not significantly different, and 0.155 and 0.072 for LTDR but significantly different. This shows that the adjustment speed for LTDR slows down during the crisis, as predicted by the literature, but the speed adjustment of STDR is not affected by states change. These different patterns between the two ratios and the respective relationships with their regressors are explored in finer detail later in sections 3.2 and 3.3 .

We also observe some differences in the behaviour of our regressors in the two periods. Given the predominant role of the lagged debt ratio and the collinearity among the regressors, the effect of the firm and macro regressors cannot be easily extracted. Consequently, in the following section, we not only perform hypothesis testing on the individual multiplicative dummy, but also group these dummies across firm and macro type. Nevertheless, we find that the firm-specific determinants that maintain a persistent and stable effect across states and all forms of debt ratio's dynamic determination are the asset structure and the cash to total assets ratios, while all remaining firm-specific ratios are either non-significant or not stable across forms and states.

\footnotetext{
${ }^{4}$ Given that the estimates of the lagged debt ratio were so high, we performed panel unit root tests: the z-statistic of Harris and Tzavalis (1999) and the two t-statistics of Im et al. (2003). We applied the tests to TDR, LTDR and STDR for the whole sample and the two sub-periods on the full balanced subsample. In majority of the cases unit root was rejected, but there were instances that it was not. However, the small T sample size makes these results on panel unit roots difficult to interpret.
} 
Table 2

Regression results

Estimated coefficients of regressors in periods 2005-2008 and 2009-2014, along with the difference across these periods. z-statistics for significance in parenthesis. Significant ***at $1 \%$, **at $5 \%$, *at $10 \%$. Wald statistic, Arellano-Bond (AB) statistics for the first five lags, Modified Wald (MW) statistic, Sargan statistic, Hansen statistic and their p-values in parenthesis. Coefficients of determination $R^{2}$ and $R_{\text {noFE }}^{2}$ with and without the estimated fixed effects. Sample size: 132,769, number of instruments: 212 for TDR, 192 for STDR, 224 for LTDR.

\begin{tabular}{|c|c|c|c|c|c|c|c|c|c|}
\hline & \multicolumn{3}{|c|}{ TDR } & \multicolumn{3}{|c|}{ STDR } & \multicolumn{3}{|c|}{ LTDR } \\
\hline \multicolumn{10}{|c|}{ Panel A: Estimates and z-statistics } \\
\hline & $2005-08$ & $2009-14$ & Diff. $T 1$ & 2005-08 & $2009-14$ & Diff. $T 1$ & $2005-08$ & $2009-14$ & Diff. $T 1$ \\
\hline L.DR & $\begin{array}{l}0.922 * * * \\
(148.51)\end{array}$ & $\begin{array}{l}0.929 * * * \\
(234.83)\end{array}$ & $\begin{array}{l}0.007 \\
(0.98)\end{array}$ & $\begin{array}{l}0.901 * * * \\
(100.36)\end{array}$ & $\begin{array}{c}0.887 * * * \\
(140.10)\end{array}$ & $\begin{array}{l}-0.014 \\
(-1.47)\end{array}$ & $\begin{array}{l}0.855^{* * *} \\
(126.09)\end{array}$ & $\begin{array}{l}0.928 * * * \\
(178.55)\end{array}$ & $\begin{array}{c}0.073 * * * \\
(9.35)\end{array}$ \\
\hline L.AS & $\begin{array}{c}-0.006^{* * *} \\
(-4.24)\end{array}$ & $\begin{array}{c}-0.006^{* * *} \\
(-6.21)\end{array}$ & $\begin{array}{l}0.000 \\
(0.08)\end{array}$ & $\begin{array}{l}-0.003 \\
(-1.30)\end{array}$ & $\begin{array}{c}-0.006 * * * \\
(-5.06)\end{array}$ & $\begin{array}{c}-0.004^{* *} \\
(-2.19)\end{array}$ & $\begin{array}{c}-0.002 * * \\
(-2.40)\end{array}$ & $\begin{array}{c}-0.003^{* * *} \\
(-5.82)\end{array}$ & $\begin{array}{l}-0.001 \\
(-1.59)\end{array}$ \\
\hline L.SIZE & $\begin{array}{c}0.001^{* *} \\
(2.16)\end{array}$ & $\begin{array}{c}-0.002^{* * *} \\
(-7.44)\end{array}$ & $\begin{array}{c}-0.004^{* * *} \\
(-5.57)\end{array}$ & $\begin{array}{c}0.004^{* * *} \\
(4.55)\end{array}$ & $\begin{array}{c}0.000 \\
(-0.62)\end{array}$ & $\begin{array}{c}-0.004^{* * *} \\
(-4.64)\end{array}$ & $\begin{array}{c}0.000 \\
(-0.33)\end{array}$ & $\begin{array}{c}-0.001^{* * *} \\
(-7.40)\end{array}$ & $\begin{array}{c}-0.001 * * * \\
(-3.19)\end{array}$ \\
\hline L.GR & $\begin{array}{l}-0.004 \\
(-0.91)\end{array}$ & $\begin{array}{c}0.000 \\
(-0.01)\end{array}$ & $\begin{array}{l}0.004 \\
(0.67)\end{array}$ & $\begin{array}{l}0.006 \\
(0.71)\end{array}$ & $\begin{array}{l}0.006 \\
(1.19)\end{array}$ & $\begin{array}{l}0.000 \\
(0.02)\end{array}$ & $\begin{array}{c}0.001^{* *} \\
(2.23)\end{array}$ & $\begin{array}{c}0.000 \\
(-0.39)\end{array}$ & $\begin{array}{c}-0.001^{*} \\
(-1.75)\end{array}$ \\
\hline L.PR & $\begin{array}{c}0.029 * * \\
(2.33)\end{array}$ & $\begin{array}{c}0.018^{* *} \\
(2.17)\end{array}$ & $\begin{array}{l}-0.010 \\
(-0.75)\end{array}$ & $\begin{array}{l}0.014 \\
(0.98)\end{array}$ & $\begin{array}{l}-0.012 \\
(-1.27)\end{array}$ & $\begin{array}{l}-0.027^{*} \\
(-1.74)\end{array}$ & $\begin{array}{c}-0.020^{* * *} \\
(-5.93)\end{array}$ & $\begin{array}{c}-0.017^{* * *} \\
(-5.69)\end{array}$ & $\begin{array}{l}0.003 \\
(0.73)\end{array}$ \\
\hline L.NDTS & $\begin{array}{l}-0.027 \\
(-1.04)\end{array}$ & $\begin{array}{l}-0.006 \\
(-0.29)\end{array}$ & $\begin{array}{l}0.021 \\
(0.65)\end{array}$ & $\begin{array}{l}-0.052 \\
(-1.62)\end{array}$ & $\begin{array}{l}0.007 \\
(0.30)\end{array}$ & $\begin{array}{l}0.059 * \\
(1.95)\end{array}$ & $\begin{array}{l}-0.004 \\
(-0.42)\end{array}$ & $\begin{array}{c}-0.023^{* * *} \\
(-2.64)\end{array}$ & $\begin{array}{l}-0.018 \\
(-1.37)\end{array}$ \\
\hline L.RISK & $\begin{array}{c}-0.008^{* *} \\
(-2.56)\end{array}$ & $\begin{array}{c}0.021 * * * \\
(5.71)\end{array}$ & $\begin{array}{c}0.029 * * * \\
(6.04)\end{array}$ & $\begin{array}{c}-0.017^{* *} \\
(-1.97)\end{array}$ & $\begin{array}{c}0.012^{* * *} \\
(3.08)\end{array}$ & $\begin{array}{c}0.029 * * * \\
(3.38)\end{array}$ & $\begin{array}{l}0.001 \\
(0.83)\end{array}$ & $\begin{array}{l}0.000 \\
(0.18)\end{array}$ & $\begin{array}{l}-0.001 \\
(-0.43)\end{array}$ \\
\hline L.NTCS & $\begin{array}{l}0.000 \\
(0.02)\end{array}$ & $\begin{array}{c}0.000 \\
(-0.59)\end{array}$ & $\begin{array}{c}0.000 \\
(-0.36)\end{array}$ & $\begin{array}{l}0.001 \\
(0.44)\end{array}$ & $\begin{array}{l}0.001 \\
(0.96)\end{array}$ & $\begin{array}{l}0.000 \\
(0.03)\end{array}$ & $\begin{array}{l}-0.001 \\
(-0.87)\end{array}$ & $\begin{array}{l}0.000 \\
(0.69)\end{array}$ & $\begin{array}{l}0.001 \\
(1.13)\end{array}$ \\
\hline L.CASHTA & $\begin{array}{c}-0.030^{* * *} \\
(-5.14)\end{array}$ & $\begin{array}{c}-0.031^{* * *} \\
(-7.41)\end{array}$ & $\begin{array}{l}-0.001 \\
(-0.20)\end{array}$ & $\begin{array}{l}-0.009 \\
(-1.22)\end{array}$ & $\begin{array}{c}-0.017^{* * *} \\
(-3.59)\end{array}$ & $\begin{array}{l}-0.008 \\
(-1.05)\end{array}$ & $\begin{array}{c}-0.017^{* * *} \\
(-7.33)\end{array}$ & $\begin{array}{c}-0.012^{* * *} \\
(-6.73)\end{array}$ & $\begin{array}{l}0.005^{*} \\
(1.76)\end{array}$ \\
\hline L.FINEXP & $\begin{array}{l}-0.004 \\
(-0.15)\end{array}$ & $\begin{array}{c}0.028^{* * *} \\
(2.85)\end{array}$ & $\begin{array}{l}0.032 \\
(1.20)\end{array}$ & $\begin{array}{l}0.029 \\
(1.04)\end{array}$ & $\begin{array}{l}0.003 \\
(0.22)\end{array}$ & $\begin{array}{l}-0.027 \\
(-1.04)\end{array}$ & $\begin{array}{c}0.028^{* *} \\
(2.39)\end{array}$ & $\begin{array}{c}0.023^{* *} \\
(2.01)\end{array}$ & $\begin{array}{l}-0.005 \\
(-0.35)\end{array}$ \\
\hline L.CRED & $\begin{array}{c}0.193^{* * *} \\
(3.34)\end{array}$ & $\begin{array}{c}0.079 * * * \\
(9.06)\end{array}$ & $\begin{array}{l}-0.115^{*} \\
(-1.95)\end{array}$ & $\begin{array}{l}0.002 \\
(0.03)\end{array}$ & $\begin{array}{c}0.048^{* * *} \\
(6.11)\end{array}$ & $\begin{array}{l}0.046 \\
(0.72)\end{array}$ & $\begin{array}{c}0.123^{* * *} \\
(3.63)\end{array}$ & $\begin{array}{c}0.042^{* * *} \\
(8.16)\end{array}$ & $\begin{array}{c}-0.081^{* *} \\
(-2.36)\end{array}$ \\
\hline L.INFL & $\begin{array}{l}-0.238 \\
(-1.22)\end{array}$ & $\begin{array}{l}-0.015 \\
(-0.73)\end{array}$ & $\begin{array}{l}0.223 \\
(1.14)\end{array}$ & $\begin{array}{l}-0.125 \\
(-0.63)\end{array}$ & $\begin{array}{l}-0.013 \\
(-0.70)\end{array}$ & $\begin{array}{l}0.112 \\
(0.57)\end{array}$ & $\begin{array}{l}-0.182 \\
(-1.57)\end{array}$ & $\begin{array}{l}-0.001 \\
(-0.12)\end{array}$ & $\begin{array}{l}0.181 \\
(1.56)\end{array}$ \\
\hline L.INTR & $\begin{array}{c}-0.284^{* *} \\
(-2.57) \\
\end{array}$ & $\begin{array}{c}0.777 * * * \\
(10.80) \\
\end{array}$ & $\begin{array}{c}1.061^{* * * *} \\
(8.20)\end{array}$ & $\begin{array}{c}-0.478^{* * *} \\
(-4.03) \\
\end{array}$ & $\begin{array}{c}0.240 * * * \\
(4.05) \\
\end{array}$ & $\begin{array}{c}0.718^{* * *} \\
(5.45) \\
\end{array}$ & $\begin{array}{l}-0.033 \\
(-0.52) \\
\end{array}$ & $\begin{array}{c}0.499 * * * \\
(11.70) \\
\end{array}$ & $\begin{array}{c}0.532 * * * \\
(7.05) \\
\end{array}$ \\
\hline \multicolumn{10}{|c|}{ Panel B: Diagnostic tests and p-values } \\
\hline & Wald & $\mathrm{AB}(1)$ & $\mathrm{AB}(2)$ & Wald & $\mathrm{AB}(1)$ & $\mathrm{AB}(2)$ & Wald & $\mathrm{AB}(1)$ & $\mathrm{AB}(2)$ \\
\hline & $\begin{array}{l}418856 \\
(0.000)\end{array}$ & $\begin{array}{l}-43.53 \\
(0.000)\end{array}$ & $\begin{array}{c}5.03 \\
(0.000) \\
\end{array}$ & $\begin{array}{l}150590 \\
(0.000)\end{array}$ & $\begin{array}{l}-42.57 \\
(0.000)\end{array}$ & $\begin{array}{c}5.16 \\
(0.000)\end{array}$ & $\begin{array}{l}91686 \\
(0.000)\end{array}$ & $\begin{array}{l}-34.81 \\
(0.000)\end{array}$ & $\begin{array}{c}1.17 \\
(0.243)\end{array}$ \\
\hline & $\mathrm{AB}(3)$ & $\mathrm{AB}(4)$ & $\mathrm{AB}(5)$ & $\mathrm{AB}(3)$ & $\mathrm{AB}(4)$ & $\mathrm{AB}(5)$ & $\mathrm{AB}(3)$ & $\mathrm{AB}(4)$ & $\mathrm{AB}(5)$ \\
\hline & $\begin{array}{c}0.25 \\
(0.801)\end{array}$ & $\begin{array}{c}1.56 \\
(0.119)\end{array}$ & $\begin{array}{c}-0.29 \\
(0.769)\end{array}$ & $\begin{array}{c}1.62 \\
(0.106)\end{array}$ & $\begin{array}{c}0.86 \\
(0.390)\end{array}$ & $\begin{array}{c}-1.06 \\
(0.291)\end{array}$ & $\begin{array}{c}-0.84 \\
(0.399)\end{array}$ & $\begin{array}{c}1.52 \\
(0.129)\end{array}$ & $\begin{array}{c}-0.36 \\
(0.721)\end{array}$ \\
\hline & MW & Sargan & Hansen & MW & Sargan & Hansen & MW & Sargan & Hansen \\
\hline & $\begin{array}{c}1.6 \mathrm{E}+41 \\
(0.000)\end{array}$ & $\begin{array}{l}904.73 \\
(0.000) \\
\end{array}$ & $\begin{array}{l}641.74 \\
(0.000) \\
\end{array}$ & $\begin{array}{c}6.7 \mathrm{E}+40 \\
(0.000)\end{array}$ & $\begin{array}{l}514.69 \\
(0.000) \\
\end{array}$ & $\begin{array}{l}438.23 \\
(0.000) \\
\end{array}$ & $\begin{array}{c}3.1 \mathrm{E}+40 \\
(0.000)\end{array}$ & $\begin{array}{c}1349.95 \\
(0.000) \\
\end{array}$ & $\begin{array}{l}664.27 \\
(0.000) \\
\end{array}$ \\
\hline \multicolumn{10}{|c|}{ Panel C: Coefficients of determination } \\
\hline & $2005-08$ & $2009-14$ & $2005-14$ & $2005-08$ & $2009-14$ & $2005-14$ & $2005-08$ & $2009-14$ & $2005-14$ \\
\hline $\begin{array}{c}R^{2} \\
R_{\text {noFE }}^{2}\end{array}$ & $\begin{array}{l}81.4 \% \\
79.0 \% \\
\end{array}$ & $\begin{array}{l}84.1 \% \\
82.0 \% \\
\end{array}$ & $\begin{array}{l}82.9 \% \\
80.7 \% \\
\end{array}$ & $\begin{array}{l}76.2 \% \\
74.1 \% \\
\end{array}$ & $\begin{array}{l}75.0 \% \\
72.1 \% \\
\end{array}$ & $\begin{array}{l}75.6 \% \\
73.1 \% \\
\end{array}$ & $\begin{array}{l}73.8 \% \\
69.5 \% \\
\end{array}$ & $\begin{array}{l}84.5 \% \\
82.3 \% \\
\end{array}$ & $\begin{array}{l}80.3 \% \\
77.2 \% \\
\end{array}$ \\
\hline
\end{tabular}


Regarding the macroeconomic variables, credit expansion has a persistent and relatively strong and positive effect across states and forms of ratios, inflation is insignificant and interest rates show an interesting shift from relatively weak and negative, as expected, effect before the crisis to strong and positive effect during the crisis. This positive effect of interest rates with leverage during crisis reflects the results of the study of Karpavičius and $\mathrm{Yu}$ (2017), that firms target their leverage ratio at lower levels during recessions when interest rates are also decreasing.

The results from the diagnostic tests are satisfactory. The Wald statistic implies a very good fit for all debt ratios, as expected, given the high autoregressive parameter. The results of the Arellano-Bond statistics for LTDR find no autocorrelation in the residuals and so we used the $1^{\text {st }}$ lag of the predetermined regressors for instruments. However, for TDR we find $1^{\text {st }}$-order autocorrelation and for STDR we find $1^{\text {st }}$ and weak $2^{\text {nd }}$-order autocorrelation in the error term. To secure that the moment conditions are satisfied for GMM estimation, we take the $2^{\text {nd }}$ lag of the predetermined regressors for instruments for TDR and the $3^{\text {rd }}$ lag for STDR. It is interesting to notice again the differences in the dynamics of the three forms of debt ratio. Shocks to the LTDR die out in the same year, while those for STDR seem to last 1 or possible 2 years. Consequently, the case for TDR, is between its two counterparts.

The modified Wald statistic finds severe heteroskedasticity in all cases. This does not cause a problem with the estimation, but it does render the Sargan statistic for overidentifying restrictions non-robust ${ }^{5}$. On the other hand, the large number of instruments weakens the Hansen statistic for overidentifying restrictions ${ }^{6}$. For all debt ratios, both statistics reject the validity of the moment conditions. However, we cannot conclude with certainty if this is the case given the lack of robustness of these statistics.

Last, we find high coefficients of determination for all debt ratios and periods confirming the good fit of the model and in line with the high values of the autoregressive parameter. We do not observe much difference between the two coefficients of determination $R^{2}$ and $R_{n o F E}^{2}$, with and without the estimated fixed effects. This suggests that unobserved heterogeneity in model (4) is weak.

\footnotetext{
${ }^{5}$ Arellano and Bond (1991) and Pitt (2011) report simulations where the Sargan statistic over-rejects in the presence of heteroskedasticity.

${ }^{6}$ Bowsher (2002) report simulations where the Hansen statistics under-rejects with a large number of instruments in the context of a simple panel autoregressive model.
} 


\subsection{Multiplicative dummies' significance between states}

We focus our analysis on the relative importance and the subsequent differences between firm-specific and macroeconomic variables, between the macroeconomic states of growth and recession, and across the three forms of leverage. We thus perform hypothesis testing (denoted as $T$ for each hypothesis below) on the significance of the multiplicative dummies. Specifically, we look at the significance of each coefficient,

$$
H_{0}: \delta^{c}=0, H_{0}: \beta_{k}^{c}=0, k=1, \ldots, K, H_{0}: \gamma_{j}^{c}=0, j=1, \ldots, J,
$$

as well as the joint significance of the multiplicative firm and macro dummies,

$$
H_{0}: \beta_{1}^{c}=\cdots=\beta_{K}^{c}=\gamma_{1}^{c}=\cdots=\gamma_{J}^{c}=0,
$$

of the multiplicative firm dummies,

$$
H_{0}: \beta_{1}^{c}=\cdots=\beta_{K}^{c}=0
$$

and of the multiplicative macro dummies,

$$
H_{0}: \gamma_{1}^{c}=\cdots=\gamma_{J}^{c}=0 \text {. }
$$

On $T 1$, results show (Diff. column in Table 2) that the hypothesis $H_{0}: \delta^{c}=0$ is rejected for LTDR and not rejected for STDR, meaning that the adjustment speed slows down for LTDR during the crisis, but does not change for STDR. Specifically, and as discussed before, the adjustment speed for STDR is higher in the recessionary period but not significantly different from the growth period, whereas speed adjustment of the LTDR significantly slows down during crisis. Regarding TDR, the result for the adjustment speed is mainly driven by that for STDR; this is expected given that on average STDR forms the bigger part of TDR (see Table 1).

Concerning the hypotheses $H_{0}: \beta_{k}^{c}=0$ and $H_{0}: \gamma_{j}^{c}=0$, we reject for $k=\mathrm{AS}$, SIZE, PR, NDTS, RISK, $j=$ INTR for STDR; $k=\mathrm{SIZE}, \mathrm{GR}, \mathrm{CASHTA}, j=\mathrm{CRED}$, INFL for LTDR; $k=$ SIZE, RISK, $j=$ CRED, INTR for TDR. Hence, there are firmspecific and macroeconomic regressors that affect differently each of the debt ratios in the two states. Interestingly, some regressors that change significantly between states for either STDR or LTDR, do not do so for TDR; there seems to be a cancellation effect when the two forms of debt are put together in the total one.

Table 3 reports the results of the hypotheses $T 2, T 3$ and $T 4$ respectively. Results show that all hypotheses are rejected for all three types of debt ratios. Hence, all the multiplicative dummies for firm and macro variables are jointly significant, as well as each of the group of the firm and macro multiplicative dummies. Therefore, the effects 
on debt ratios of firm-specific and macro variables are significantly different between the two periods.

Table 3

Significance of firm and macro multiplicative dummies

Wald statistics for joint significance and their p-values in parenthesis.

\begin{tabular}{|ccc|ccc|ccc|}
\hline \multicolumn{3}{|c|}{ TDR } & \multicolumn{3}{c|}{ STDR } & \multicolumn{3}{c|}{ LTDR } \\
\hline$T 2$ & $T 3$ & $T 4$ & $T 2$ & $T 3$ & $T 4$ & $T 2$ & $T 3$ & $T 4$ \\
\hline 172.08 & 78.73 & 85.85 & 79.60 & 33.46 & 48.26 & 117.82 & 26.57 & 60.29 \\
$(0.000)$ & $(0.000)$ & $(0.000)$ & $(0.000)$ & $(0.000)$ & $(0.000)$ & $(0.000)$ & $(0.002)$ & $(0.000)$ \\
\hline
\end{tabular}

Having found these different effects, we next examine the contributions of the firm and macro variables at the sample mean of the debt ratios in each state, as well as compare these contributions in absolute terms. Specifically, we evaluate the sample mean of the firm and macro variables in each of the two periods and test whether the contributions to the mean of debt ratio of the firm and macro variables are significant and if the absolute magnitude of these contributions are equal in each period. We test the hypotheses:

$$
\begin{array}{lr}
H_{0}: \sum_{k}^{K} \beta_{k} \bar{X}_{k}^{(1)}=0, H_{0}: \sum_{k}^{K}\left(\beta_{k}+\beta_{k}^{c}\right) \bar{X}_{k}^{(2)}=0, & T 5 \\
H_{0}: \sum_{j}^{J} \gamma_{j} \bar{M}_{j}^{(1)}=0, H_{0}: \sum_{j}^{J}\left(\gamma_{j}+\gamma_{j}^{c}\right) \bar{M}_{j}^{(2)},=0 & T 6 \\
H_{0}: \sum_{k}^{K} \beta_{k} \bar{X}_{k}^{(1)}=\sum_{k}^{K}\left(\beta_{k}+\beta_{k}^{c}\right) \bar{X}_{k}^{(2)}, & T 7 \\
H_{0}: \sum_{j}^{J} \gamma_{j} \bar{M}_{j}^{(1)}=\sum_{j}^{J}\left(\gamma_{j}+\gamma_{j}^{c}\right) \bar{M}_{j}^{(2)}, & T 8 \\
H_{0}:\left|\sum_{k}^{K} \beta_{k} \bar{X}_{k}^{(1)}\right|=\left|\sum_{j}^{J} \gamma_{j} \bar{M}_{j}^{(1)}\right| \text { and } & T 9 \\
H_{0}:\left|\sum_{k}^{K}\left(\beta_{k}+\beta_{k}^{c}\right) \bar{X}_{k}^{(2)}\right|=\left|\sum_{j}^{J}\left(\gamma_{j}+\gamma_{j}^{c}\right) \bar{M}_{j}^{(2)}\right|, & T 10
\end{array}
$$

where $\bar{X}_{k}^{(p)}$ and $\bar{M}_{j}^{(p)}$ are the sample mean of the $k$-th lagged firm regressor and $j$-th lagged macro regressor in the $p$-th period, $p=1,2$. Table 4 reports the results from hypothesis testing $T 5$ to $T 10$.

Concerning the hypothesis testing $T 5$ and $T 6$, we find that in the growth period (2005-08), the contribution of the firm variables to the mean of TDR and LTDR is insignificant, but significant for STDR, while that of the macro variables is significant for STDR and LTDR and marginally significant (at 10\%) for TDR. During recession (2009-14), the contribution of the firm and macro variables are significant for all debt 
ratios, with the exception of the firm variables for STDR where the result is marginally significant (at 10\%).

Table 4

Significance of contributions of firm and macro variables

Wald statistics for restrictions and their p-values in parenthesis.

\begin{tabular}{|c|c|c|c|c|c|c|c|c|}
\hline \multicolumn{3}{|c|}{ TDR } & \multicolumn{3}{|c|}{ STDR } & \multicolumn{3}{|c|}{ LTDR } \\
\hline \multicolumn{9}{|c|}{ Firm variables } \\
\hline 2005-08 & 2009-14 & Diff. & $2005-08$ & $2009-14$ & Diff. & $2005-08$ & 2009-14 & Diff. \\
\hline T5 & T5 & $T 7$ & T5 & T5 & $T 7$ & T5 & T5 & $T 7$ \\
\hline $\begin{array}{c}0.87 \\
(0.351)\end{array}$ & $\begin{array}{c}68.86 \\
(0.000)\end{array}$ & $\begin{array}{c}22.27 \\
(0.000)\end{array}$ & $\begin{array}{c}16.88 \\
(0.000)\end{array}$ & $\begin{array}{c}2.81 \\
(0.094)\end{array}$ & $\begin{array}{c}20.57 \\
(0.000)\end{array}$ & $\begin{array}{c}1.03 \\
(0.309)\end{array}$ & $\begin{array}{c}69.26 \\
(0.000)\end{array}$ & $\begin{array}{c}9.20 \\
(0.002)\end{array}$ \\
\hline \multicolumn{9}{|c|}{ Macro variables } \\
\hline $2005-08$ & 2009-14 & Diff. & $2005-08$ & $2009-14$ & Diff. & 2005-08 & 2009-14 & Diff. \\
\hline T6 & T6 & $T 8$ & T6 & T6 & $T 8$ & T6 & T6 & $T 8$ \\
\hline $\begin{array}{c}3.09 \\
(0.079) \\
\end{array}$ & $\begin{array}{l}124.94 \\
(0.000)\end{array}$ & $\begin{array}{c}12.89 \\
(0.000) \\
\end{array}$ & $\begin{array}{c}7.82 \\
(0.005)\end{array}$ & $\begin{array}{c}18.72 \\
(0.000)\end{array}$ & $\begin{array}{c}16.93 \\
(0.000)\end{array}$ & $\begin{array}{c}15.01 \\
(0.000) \\
\end{array}$ & $\begin{array}{l}143.36 \\
(0.000) \\
\end{array}$ & $\begin{array}{c}3.96 \\
(0.047) \\
\end{array}$ \\
\hline \multicolumn{9}{|c|}{ Firm versus macro variables } \\
\hline $2005-08$ & & 2009-14 & 2005-0 & & $009-14$ & $2005-08$ & & $2009-14$ \\
\hline T9 & & $T 10$ & T9 & & $T 10$ & T9 & & T10 \\
\hline $\begin{array}{c}0.16 \\
(0.694) \\
\end{array}$ & & $\begin{array}{l}228.92 \\
(0.000)\end{array}$ & $\begin{array}{l}185.41 \\
(0.000)\end{array}$ & & $\begin{array}{l}170.75 \\
(0.000)\end{array}$ & $\begin{array}{l}971.43 \\
(0.000) \\
\end{array}$ & & $\begin{array}{l}372.70 \\
(0.000)\end{array}$ \\
\hline
\end{tabular}

Results also show that both hypotheses $T 7$ and $T 8$ are rejected and therefore the contributions of the firm and macro variables to the mean are different across the two states. Finally, both hypotheses $T 9$ and $T 10$ are rejected in both periods for STDR and LTDR, but only for the second period for TDR. Hence, the absolute contribution of the firm variables to the mean of STDR and LTDR is different from that of the macro variables in both periods. This is also the case for TDR for the recessionary period, but not for the growth period. The above results indicate that there is a clear differentiation between the dynamic determination of the two forms of debt, short- and long-term.

Overall, our hypothesis testing suggests that there are significant differences in the effect of the regressors (lagged debt ratio, firm-specific and macroeconomic) across the two states and between short- and long-term debt ratios. As such, in the next section we decompose the sample mean of the debt ratios across the regressors (lagged debt ratio, firm-specific and macroeconomic) to compare their contributions. 


\subsection{Mean decomposition}

We analyze the effect on the sample mean of the debt ratio by each of the three components:

- the lagged debt ratio $D R_{i, t-1}$ (with its multiplicative dummy),

- the lagged firm regressors $X_{i, t-1}$ (with their multiplicative dummies),

- the lagged macro regressors $M_{t-1}$ (with their multiplicative dummies).

First, we evaluate the average fitted debt ratio and the contribution to this average of each of the above three components for each year. In particular, for each $i$ firm and $t$ year, we calculate the fitted values $\widehat{D R}_{i, t}$ from model (4) and evaluate the contribution from the lagged debt ratio and the two sets of the regressors, that is, the variables $\widehat{D R}_{i, t, l}=\hat{\delta} D R_{i, t-1}+\hat{\delta}^{c} D R_{i, t-1} C_{t}, \quad \widehat{D R}_{i, t, X}=\hat{\beta}^{\prime} X_{i, t-1}+\hat{\beta}^{c \prime} X_{i, t-1} C_{t}$ and $\widehat{D R}_{i, t, M}=$ $\hat{\gamma}^{\prime} M_{t-1}+\hat{\gamma}^{c \prime} M_{t-1} C_{t}$. Last, we average the true values $D R_{i, t}$, the fitted values $\widehat{D R}_{i, t}$ and the contributions $\widehat{D R}_{i, t, l}, \widehat{D R}_{i, t, X}, \widehat{D R}_{i, t, M}$ across firms for each year $t$, denoting these averages by $\overline{D R}_{t} \cdot \overline{\widehat{D R}}_{t}, \overline{\widehat{D R}}_{t, l}, \overline{\widehat{D R}}_{t, X}$ and $\overline{\widehat{D R}}_{t, M}$. Notice that $\overline{\widehat{D R}}_{t}=\overline{\widehat{D R}}_{t, l}+\overline{\widehat{D R}}_{t, X}+$ $\overline{\widehat{D R}}_{t, M}$. Results are presented in Table 5 below.

Table 5

Decomposing the mean of debt ratio

Average debt ratio, averaged fitted debt ratio and the three components (lagged debt ratio, firm and macro variables)

\begin{tabular}{|c|c|c|c|c|c|c|c|c|c|c|c|c|c|c|c|}
\hline & \multicolumn{5}{|c|}{ TDR } & \multicolumn{5}{|c|}{ STDR } & \multicolumn{5}{|c|}{ LTDR } \\
\hline & $\overline{D R}_{t}$ & $\overline{\widehat{D R}}_{t}$ & $\overline{\widehat{D R}}_{t, l}$ & $\overline{\widehat{D R}}_{t, X}$ & $\widehat{\widehat{D R}}_{t, M}$ & $\overline{D R}_{t}$ & $\overline{\widehat{D R}}_{t}$ & $\widehat{\widehat{D R R}}_{t, l}$ & $\overline{\widehat{D R}}_{t, X}$ & $\overline{\widehat{D R}}_{t, M}$ & $\overline{D R}_{t}$ & $\widehat{\widehat{D R}}_{t}$ & $\widehat{\widehat{D R}}_{t, l}$ & $\overline{\widehat{D R}}_{t, X}$ & $\widehat{D R}_{t, M}$ \\
\hline 2005 & 0.193 & 0.193 & 0.169 & 0.008 & 0.015 & 0.141 & 0.138 & 0.121 & 0.049 & -0.031 & 0.052 & 0.055 & 0.043 & -0.005 & 0.017 \\
\hline 2006 & 0.205 & 0.204 & 0.177 & 0.009 & 0.018 & 0.146 & 0.145 & 0.126 & 0.050 & -0.031 & 0.059 & 0.058 & 0.044 & -0.005 & 0.019 \\
\hline 2007 & 0.212 & 0.212 & 0.188 & 0.009 & 0.015 & 0.142 & 0.147 & 0.131 & 0.051 & -0.034 & 0.070 & 0.063 & 0.050 & -0.005 & 0.018 \\
\hline 2008 & 0.219 & 0.219 & 0.195 & 0.009 & 0.015 & 0.144 & 0.142 & 0.128 & 0.051 & -0.037 & 0.075 & 0.074 & 0.060 & -0.005 & 0.019 \\
\hline 2009 & 0.233 & 0.231 & 0.203 & -0.037 & 0.065 & 0.145 & 0.145 & 0.127 & -0.007 & 0.025 & 0.088 & 0.088 & 0.070 & -0.020 & 0.038 \\
\hline 2010 & 0.220 & 0.223 & 0.215 & -0.037 & 0.045 & 0.134 & 0.136 & 0.128 & -0.008 & 0.016 & 0.086 & 0.086 & 0.081 & -0.020 & 0.025 \\
\hline 2011 & 0.213 & 0.213 & 0.209 & -0.036 & 0.039 & 0.138 & 0.138 & 0.131 & -0.006 & 0.014 & 0.075 & 0.074 & 0.072 & -0.019 & 0.021 \\
\hline 2012 & 0.212 & 0.207 & 0.198 & -0.035 & 0.045 & 0.138 & 0.133 & 0.123 & -0.006 & 0.015 & 0.075 & 0.074 & 0.069 & -0.019 & 0.024 \\
\hline 2013 & 0.204 & 0.201 & 0.191 & -0.035 & 0.046 & 0.130 & 0.128 & 0.118 & -0.006 & 0.016 & 0.073 & 0.073 & 0.067 & -0.019 & 0.025 \\
\hline 2014 & 0.196 & 0.192 & 0.183 & -0.037 & 0.046 & 0.115 & 0.112 & 0.105 & -0.007 & 0.015 & 0.080 & 0.080 & 0.073 & -0.019 & 0.026 \\
\hline
\end{tabular}

Combining the results of Tables 4 and 5, we conclude the following: 
Regarding TDR, the contribution of the firm variables to the average TDR is positive (but insignificant, see T5) in the first period and turns negative (and significant, see T5) in the second period, with the change across the two periods being negative (and significant, see T7). The contribution of the macro variables to the average TDR is positive (and marginally significant, see T6) in the first period and is positive (and significant, see T6) in the second period, with the change across the two periods being positive (and significant, see T8). The contribution of the macro variables is slightly higher in the first period than that of the firm variables (but the difference is insignificant, see T9), while in the second period the contribution of the macro variables is higher in absolute value than that of the firm variables (and the difference is significant, see T10).

On STDR, the contribution of the firm variables to the average STDR is positive (and insignificant, see T5) in the first period and turns negative (and marginally significant, see T5) in the second period, with the change across the two periods being negative (and significant, see T7). The contribution of the macro variables to the average STDR is negative (and significant, see T6) in the first period and is positive (and significant, see T6) in the second period, with the change across the two periods being positive (and significant, see $T 8$ ). The contribution of the firm variables is higher in absolute value than that of the macro variables $n$ the first period (and the difference is significant, see T9), while in the second period the contribution of the macro variables is higher in absolute value than that of the firm variables (and the difference is significant, see $T 10)$.

Last, on LTDR, the contribution of the firm variables to the average LTDR is negative (but insignificant, see T5) in the first period and becomes even more negative (and significant, see T5) in the second period, with the change across the two periods being negative (and significant, see T7). The contribution of the macro variables to the average LTDR is positive (and significant, see T6) in both periods, with the change across the two periods being positive (and significant, see $T 8$ ). The contribution of the firm variables is higher in absolute value than that of the macro variables (and the difference is significant, see T9), while in the second period the contribution of the macro variables is higher in absolute value than that of the firm variables in the first period (and the difference is significant, see T10). Note also that for all forms of debt, the average of the fitted values of the debt ratio is very close to the average of the true debt ratio, confirming again the good fit of the model. 


\subsection{Robustness checks}

In this section, we discuss the results of our robustness checks 1 to 7 as described in Section 2.2. Table 6 shows the differences between the p-values of our model (4) and the respective check, for the ten $T$ tests (Section 3.2). We do not report the differences in p-values for each coefficient of the firm-specific and macroeconomic variables for the sake of brevity, but we discuss the main conclusions of any changes in each test.

\section{Table 6}

Differences between the p-values of the model and the respective check for T1-T10

* denotes marginal difference: the $\mathrm{p}$-value was $<1 \%$ and turns $1 \%<\mathrm{p}<10 \%$ or the $\mathrm{p}$-value was slightly above $10 \%$ and turns $1 \%<\mathrm{p}<5 \%$.

** denotes critical difference, namely when a non-significant/significant p-value turns significant/non-significant.

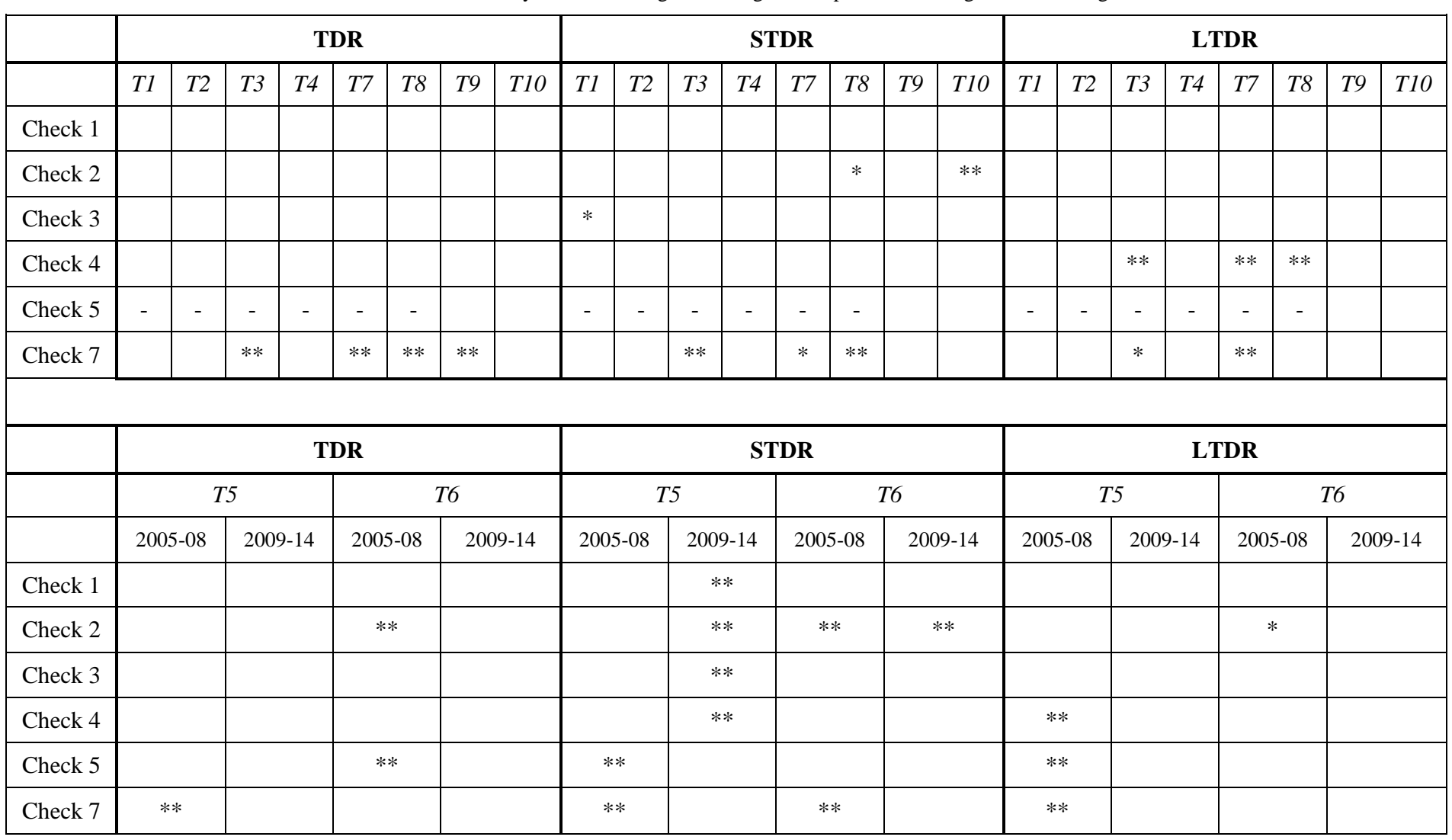

The table shows that conclusions remain unchanged in terms of p-values for most of the hypotheses and most of the checks. The only persistent change in p-value is noted for $T 5$ and the STDR, during the crisis, where p-value turns insignificant. T5 measures the contribution of the firm variables to debt ratios at the mean. Note that $T 5$ was marginally significant in our model during the crisis for the STDR, and now turns insignificant, implying that the contribution of firm variables to the mean debt ratio 
could be even less important; this reinforces our main finding, namely that the contribution of firm variables to the mean is even less important during the crisis. The effects of each check individually are discussed in the sub-sections that follow.

\subsubsection{Check 1: Allow for maximum lag in the instruments}

We use all available lags (passed the one lag used in Table 3) to instrument the predetermined regressors in the difference equation in the system GMM estimation. The z-statistics for each coefficient remain largely stable, except for a few firm and macro regressors that are border-line significant/insignificant. Conclusions from the hypothesis testing T1-T10 remain unchanged, except for T5 for STDR, which turns insignificant.

\subsubsection{Check 2: Use a full balanced subsample of the data}

We create a balanced subsample of the data. The total number of observations is approximately half of the unbalanced sample. The results from the z-statistics for each coefficient are similar to those in Table 3, except for some firm and macro regressors that are border-line significant/insignificant. We observe some differences in hypotheses testing, most of which refer to STDR. Nevertheless, we still observe similar patterns in that for all debt ratios the effects of firm and macro variables are different across the two states, and during the crisis period the macroeconomic variables are more important than firm ones, except for STDR where the two sets of variables have the same effect.

\subsubsection{Check 3: Examine firms with total debt ratio less than 100\%}

Our sample contains 202 firms (approximately 1\% of the sample) that have total debt of more than $100 \%$ at least for one year. Thus, the effects when we remove these firms are minor. All the z-statistics provide the same conclusions, expect for very few regressors that are border-line significant/insignificant. Conclusions from hypothesis testing T1-T10 are the same, except for T5 for STDR as noted above and a marginal difference in $\mathrm{p}$-value for $\mathrm{T} 1$ for STDR.

\subsubsection{Check 4: Consider only firms with non-zero debt}

We examine firms with non-zero debt (total, short or long in each case) for all available years. We drop 2,357, 3,472 and 7,255 firms for TDR, STDR and LTDR, 
representing $14 \%, 20 \%$ and $42 \%$ of the sample size respectively. The z-statistics for each coefficient remain largely unaffected, except for few firm regressors that are border-line significant/insignificant. Regarding hypotheses testing, the main affect seems to be on the LTDR, since T3, T7 and T8 turn insignificant. Nonetheless, we still observe similar patterns in that for all debt ratios the effects of firm and macro variables are different across the two states, and during the crisis the macroeconomic variables are more important than the firm-specific variables.

\subsubsection{Check 5: Split the sample in the two periods}

We break the sample period into the two states. The sample size drops significantly, especially in the first shorter period, which results in some sensitivity. The z-statistics are affected for some of the firm and macro regressors. Note that the dummies are not included in this check, so that hypothesis testing for T1-T4 and T7-T8 cannot be performed. Regarding the remaining tests the conclusions are the same except for $T 5$ for STDR and LTDR, which turn insignificant and significant respectively, and T6 for TDR which turns insignificant. However, we can still conclude that macroeconomic regressors play a more crucial role that firm ones during the recession.

\subsubsection{Check 6: Replace the macro regressors by year dummies}

We replace the macroeconomic regressors by time dummies and thus testing hypotheses T1-T10 are not relevant in our analysis to compare firm vs. macro variables. The z-statistics for each coefficient remain largely unaffected, except for few regressors that are border-line significant/insignificant. An exception is the regressors for the size, which is likely due to the fact that size has by far the lowest coefficient of variation of all regressors.

\subsubsection{Check 7: Consider different break point of when the crisis occurs.}

Last, we change the break point of our sample from 2009 to 2008 to reflect the year of the global financial crisis. We observe the largest sensitivity in this check compared to all other checks, which is expected, as in 2008 the Greek economy was not in recession and credit conditions were stable (see Figure 1). So, the sensitivity that we find could be due to misspecifying the break point. Nonetheless, most of our conclusions still remain valid: for all debt ratio forms, the macroeconomic regressors 
have different effect across the two states, and are also more important during the crisis period.

\subsection{Summary of the results}

In summary, our results show that there are differences between the effects of the firm and macro variables across the two states and for all debt ratios, with a tendency that macro contributions to the mean of debt ratio to become more important than the firm-specific variables during recession. Overall, firm variables are more important in determining STDR in the growth period, while macro variables increase their importance in the recessionary period. As regards LTDR, macro variables are more important than firm variables in determining the ratio in the entire sample period, and become even more important during the crisis. These results imply that the specificities of short-term vs. long-term debt should be considered in capital structure analyses and results and conclusions should not be based solely on total debt.

\section{Conclusions and Discussion}

Recent literature in capital structure has shed light on adjustment speed in a context of changing macroeconomic states (Cook and Tang, 2010; Öztekin and Flannery, 2012). However, all studies have focused on listed companies, while small and medium enterprises (SMEs) have not yet been explored. This is surprising, given the importance of SMEs for all national economies. Furthermore, no study has so far examined the relative importance of firm-specific vs. macroeconomic variables in changes in macroeconomic states. This is the main objective of the paper, namely to investigate whether and how the effect and contribution of firm-specific and macroeconomic variables on capital structure determination of SMEs, change in different macroeconomic states.

We first find that the main determinant of the debt ratio is its lagged value, across all three forms of leverage (short-term, long-term and total), so that the remaining firm and macroeconomic factors play a secondary role in their dynamic determination. Furthermore, short-term and long-term debt ratios follow different patterns regarding their adjustment speeds, where the adjustment speed for LTDR slows down during the crisis, while that of STDR is not affected. We also conclude that there is a clear differentiation of the effects and the contribution of the firm-specific vs. the 
macroeconomic variables for both STDR and LTDR between the two states. Specifically, firm variables are more important in determining STDR in the growth period than macro variables, while macro variables increase their importance in the recessionary period. As regards LTDR, macro variables are more important than firm variables in determining the ratio in the entire sample period, and become even more important during the crisis. Given these clear differentiations between the two forms of debt, there is no point in drawing conclusions on the total debt ratio and we thus drop our conclusions on TDR. Our conclusions are robust to most of the checks, since our conclusions remain unchanged. The only persistent change is noted for STDR, implying that the contribution of firm variables to the mean could be even less important during the crisis.

We thus provide evidence that the nature and maturity of borrowing itself affects the persistence and endurance of the relationship between determinants and borrowing, in line with the general approach of differentiating between short-term and long-term debt for SMEs (Koeter-Kant and Hernandez-Canovas, 2011; García-Teruel, and MartínezSolano, 2010; Michaelas et al., 1999). Assuming that the firm-specific factors are internal to the firm meaning that managers have a certain level of control upon these factors, while there is no such control over the macroeconomic variables, our results imply that SMEs' managers have very low levels of flexibility to alter the capital structure of the firms they manage during the crisis. In other words, SMEs are particularly vulnerable during the crisis on how their capital structure is being determined.

Our study implies that the capital structure puzzle, which was rightfully referred to as such by Myers (1984), is a multi-dimensional riddle that is simultaneously affected by the inherent specificities of the following contrasting pairs: (a) large enterprises vs. SMEs, (b) growth vs. recessionary states, (c) short-term vs. long-term debt and (d) countries' specificities vs. similarities. Regarding the practical implications of our study, when viewed by a managerial perspective, a cumbersome capital structure can be seen as an impediment in value maximization. When viewed by a regulatory perspective, this implies that regulators should provide the context within which a financial environment can exist, where better institutions will lead to lower transaction costs and higher adjustment speed of capital structure. Furthermore, this flexible financial environment is of higher importance for SMEs, when compared to large 
enterprises, since the former are relatively more constrained in access to finance and thus more vulnerable in macroeconomic state changes.

A main limitation is that our results apply to the specificities of one particular country, meaning that conclusions are restricted to economies that share similar characteristics with Greece. Additionally, the depth and persistence of the economic recession in Greece may seem as an extreme environment that is unlikely to be observed in developed economies in the near future; on the other hand, this specific environment is perhaps the ideal context to test this particular problem in question, since the two individual macroeconomic states are distinctively different. Future research could investigate whether capital structure determinants behave differently in economies with different levels of financial integration and milder differences in macroeconomic states.

\section{References}

Ang, J.S. (1991). Small business uniqueness and the theory of financial management. Journal of Small Business Finance, 1 (1), 1-13.

Ang, J.S., Chua, J.H. \& McConnell, J.J. (1982). The administrative costs of corporate bankruptcy: A note. The Journal of Finance, 37 (1), 219-226.

Arellano, M. \& Bond, S. (1991). Some tests of specification for panel data: Monte Carlo evidence and an application to employment equations. Review of Economic Studies, 58 (2), 277-297.

Arellano, M., \& Bover, O. (1995). Another look at the instrumental variable estimation of error-components models. Journal of Econometrics, 68 (1), 29-51.

Asselbergh, G. (2002). Financing Firms with Restricted Access to Financial Markets: The Use of Trade Credit and Factoring in Belgium. The European Journal of Finance, 8 (1), 2-20.

Bastos, D. D., Nakamura, W. T., \& Basso, L. F. C. (2009). Determinants of capital structure of publicly-traded companies in Latin America: the role of institutional and macroeconomic factors. Journal of international finance and economics, 9 (3), 24-39.

Baum, C.F., Caglayan, M. \& Rashid, A. (2016). Capital structure adjustments: Do macroeconomic and business risks matter?. Empirical Economics, Article not assigned to an issue - Online first article. 
Baum, C.F., Stephan, A., Talavera, O. (2009). The effects of uncertainty on the leverage of nonfinancial firms. Economic Inquiry, 47, 216-225.

Blundell, R. \& Bond, S. (1998). Initial conditions and moment restrictions in dynamic panel data models. Journal of Econometrics, 87 (1), 115-143.

Bowsher, C.G. (2002). On testing overidentifying restrictions in dynamic panel data models. Economics Letters, 77, 211-220.

Casey, E. \& O'Toole, C. (2014). Bank Lending Constraints, Trade Credit and Alternative Financing during the Financial Crisis: Evidence from European SMEs. Journal of Corporate Finance, 27, 173-193.

Choe, H., Masulis, R.W. \& Nanda, V. (1993). Common stock offerings across the business cycle: Theory and evidence. Journal of Empirical Finance, 1(1), 3-31.

Colombo, M. and Grilli, L. (2007). Funding gaps? Access to bank loans by high-tech start-ups. Small Business Economics, 29 (1), 25-46.

Cook, D. \& Tang, T. (2010). Macroeconomic conditions and capital structure adjustment speed. Journal of Corporate Finance 16 (1), 73-87.

Cressy, R. \& Olofsson, C. (1997). European SME financing: An overview. Small Business Economics, 9 (2), 87-96.

Daskalakis, N. \& Psillaki, M. (2008). Do country or firm factors explain capital structure? Evidence from SMEs in France and Greece. Applied Financial Economics, 18 (2), 87-97.

De Bettignies, J.E. \& Brander, J.A. (2007). Financing entrepreneurship: bank finance versus venture capital. Journal of Business Venturing, 22 (6), 808-832.

DeAngelo, H., \& Masulis, R.,W. (1980). Optimal capital structure under corporate and personal taxation. Journal of Financial Economics, 8 (1), 3-29.

Diamond, D., \& He, Z., (2014). A Theory of Debt Maturity: The Long and Short of Debt Overhang. The Journal of Finance, Vol. LXIX (2), 719-762.

Fan, J., Titman, S., \& Twite, G. (2012). An International Comparison of Capital Structure and Debt Maturity Choices. Journal of Financial and Quantitative Analysis, 47 (1), 23-56.

Frank, M.Z. \& Goyal, V.K. (2004). The effect of market conditions on capital structure adjustment. Finance Research Letters, 1, 47-55.

Frank, M.Z. \& Goyal, V.K., (2009). Capital structure decisions: Which factors are reliably important?. Financial Management, 38, 1-37. 
Fu, R. \& Subramanian, A., (2011). Leverage and debt maturity choices by undiversified owner-managers. Journal of Corporate Finance, 17, 888-913.

García-Teruel, P.J. \& Martínez-Solano, P., (2010). Determinants of trade credit: A comparative study of European SMEs. International Small Business Journal 28 (3), 215-233.

Gertler, M., \& Gilchrist, S. (1993). The role of credit market imperfections in the monetary transmission mechanism: Arguments and evidence. The Scandinavian Journal of Economics, 95 (1), 43-64.

Greene, W. (2000). Econometric Analysis. New York, Prentice-Hall.

Guariglia, A. \& Mateut, S. (2006). Credit channel, trade credit channel, and inventory investment: evidence from a panel of UK firms. Journal of Banking and Finance, 30, 2835-2856.

Hackbarth, D., Miao, J. \& Morellec, E. (2006). Capital structure, credit risk, and macroeconomic conditions. Journal of Financial Economics, 82 (3), 519-550.

Hall, G.C., Hutchinson, P.J. \& Michaelas, N. (2004). Determinants of the capital structure of European SMEs. Journal of Business Finance \& Accounting. 31 (5\&6), 711-728.

Halling, M., Yu, J. \& Zechner, J. (2016). Leverage dynamics over the business cycle. Journal of Financial Economics, 122, 21-41.

Hanousek, J. \& Shamshur, A. (2011). A stubborn persistence: Is the stability of leverage ratios determined by the stability of the economy?. Journal of Corporate Finance, 17 (5), 1360-1376.

Hansen, L. (1982). Large sample properties of generalized method of moments estimators. Econometrica, 50 (3), 1029-1054.

Harris, M. \& Raviv, A. (1990). Capital structure and the informational role of debt. The Journal of Finance, 45 (2), 321-349.

Harris, R. D. F. \& Tzavalis, E. (1999). Inference for unit roots in dynamic panels where the time dimension is fixed. Journal of Econometrics, 91 (2), 201-226.

Im, K. S., Pesaran, M. H. \& Shin, Y. (2003). Testing for unit roots in heterogeneous panels. Journal of Econometrics, 115 (1), 53-74.

Karpavičius, S. \& Yu, F. (2017). The Impact of Interest Rates on Firms’ Financing Policies. Journal of Corporate Finance, 45, 262-293. 
Koeter-Kant, J. \& Hernandez-Canovas, G. (2011). SME Financing in Europe: CrossCountry Determinant of Bank Loan Maturity. International Small Business Journal, 29 (5), 489-507.

Korajczyk, R.A. \& Levy, A. (2003). Capital structure choice: Macroeconomic conditions and financial constraints. Journal of Financial Economics, 68, 75-109.

Love, I., Lorenzo A. P. \& Sarria-Allende, V. (2007). Trade credit and bank credit: Evidence from recent financial crises. Journal of Financial Economics, 83 (2), 453469.

Michaelas. N., Chittenden, F. \& Poutziouris, P. (1999). Financial policy and capital structure choice in UK SMEs: Empirical evidence from company panel data. Small Business Economics, 12 (2), 113-130.

Mokhova, N. \& Zinecker, M. (2014). Macroeconomic factors and corporate capital structure. Procedia - Social and Behavioral Sciences, 110, 530-540.

Myers, S.C. (1977). Determinants of corporate borrowing. Journal of Financial Economics, 5 (2), 147-175.

Myers, S.C. (1984). The capital structure puzzle. The Journal of Finance, 39(3), 574592.

Ng, C. K., Smith, J. K. \& Smith, R. L. (1999). Evidence on the Determinants of Credit Terms Used in Inter-Firm Trade. The Journal of Finance, 54 (3), 1109-1129.

Öztekin, Ö. \& Flannery, M.J. (2012). Institutional determinants of capital structure adjustment speeds. Journal of Financial Economics, 103 (1), 88-112.

Pettit, R.R. \& Singer, R.F. (1985). Small business finance: A research agenda. Financial Management, 14 (3), 47-60.

Pitt, M.M. (2011). Overidentification tests and causality: a second response to Roodman and Morduch. Draft: Comments Welcome, https://www.researchgate.net/publication/260249759

Psillaki, M. \& Daskalakis, N. (2009). Are the determinants of capital structure country or firm specific? Evidence from SMEs. Small Business Economics, 33 (3), 319333.

Psillaki, M. \& Eleftheriou, K. (2015). Trade Credit, Bank Credit, and Flight to Quality: Evidence from French SMEs. Journal of Small Business Management, 53 (4), 12191240.

Sargan, J. (1958). The estimation of economic relationships using instrumental variables. Econometrica 26 (3), 393-415. 
Scott, J.H. (1977). Bankruptcy, secured debt, and optimal capital structure. The Journal of Finance, 32 (1), 1-19.

Sogorb-Mira, F. (2005). How SME uniqueness affects capital structure: Evidence from a 1994-1998 Spanish data panel. Small Business Economics, 25 (5), 447-457.

Titman, S. \& Wessels, R. (1988). The determinants of capital structure choice. The Journal of Finance, 43 (1), 1-19.

Torrès, O. \& Julien, P.A. (2005). Specificity and denaturing of small business. International Small Business Journal, 23 (4), 355-377.

Windmeijer, F. (2005). A finite sample correction for the variance of linear efficient two-step GMM estimators. Journal of Econometrics, 126 (1), 25-51. 